\title{
Efficacy of dietary supplementary probiotics as substitutes for antibiotic growth promoters during the starter period on growth performances, carcass traits, and immune organs of male layer chicken
}

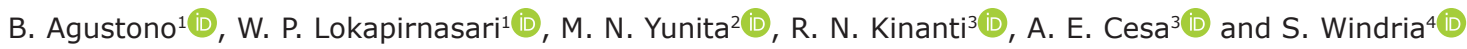

1. Department of Veterinary Science, Division of Animal Husbandry, Faculty of Veterinary Medicine, Universitas Airlangga, Surabaya, Indonesia; 2. Department of Veterinary Science, Division of Pathology Veteriner, Faculty of Veterinary Medicine, Universitas Airlangga, Surabaya, Indonesia; 3. Faculty of Veterinary Medicine, Universitas Airlangga,

Surabaya, Indonesia; 4. Department of Biomedical Sciences, Division of Microbiology, Veterinary Medicine Study Program, Faculty of Medicine, Universitas Padjadjaran, Bandung, Indonesia.

Corresponding author: B. Agustono, e-mail: bodhiagustono@fkh.unair.ac.id

Co-authors: WPL: widyaparamitalokapirnasari@gmail.com, MNY: mayanurwantanti@fkh.unair.ac.id, RNK: ratri.nur.kinanti-2019@fkh.unair.ac.id, AEC: anke.erni.cesa-2019@fkh.unair.ac.id, SW: sarasatiwindria@yahoo.com Received: 18-09-2021, Accepted: 12-01-2022, Published online: 14-02-2022

doi: www.doi.org/10.14202/vetworld.2022.324-330 How to cite this article: Agustono B, Lokapirnasari WP, Yunita MN, Kinanti RN, Cesa AE, Windria S (2022) Efficacy of dietary supplementary probiotics as substitutes for antibiotic growth promoters during the starter period on growth performances, carcass traits, and immune organs of male layer chicken, Veterinary World, 15(2): 324-330.

\begin{abstract}
Background and Aim: With the increased concerns about global protein supply, chicken meat, especially from male layer chicken, constitutes an alternative in terms of quality and carcass traits. Probiotics have been proposed for replacing antibiotic growth promoters (AGPs), which have been prohibited as poultry supplement feeds. The present study aimed to determine the efficacy of dietary supplementary probiotics during the starter period on growth performances, carcass traits, and immune organs of male layer chicken.
\end{abstract}

Materials and Methods: In this study, one hundred and eighty 1-day-old male chicks from the strain ISA brown were used. They were divided into six groups according to the feed: $100 \%$ basal feed (T0), basal feed $+2.5 \mathrm{~g} \mathrm{AGP} / \mathrm{kg}$ feed (T1), basal feed+probiotics $1 \mathrm{~mL} / \mathrm{kg}$ feed (T2), basal feed+probiotics $3 \mathrm{~mL} / \mathrm{kg}$ feed (T3), basal feed+probiotics $4 \mathrm{~mL} / \mathrm{kg}$ feed (T4), and basal feed+probiotics $5 \mathrm{~mL} / \mathrm{kg}$ feed (T5). Probiotics (Lactobacillus acidophilus, Lactobacillus plantarum, and Bifidobacterium spp.) were given at a concentration of $1.2 \times 10^{9}$ colony-forming unit $/ \mathrm{mL}$. Virginiamycin was used as AGP. ISA brown layer chicken was treated for 21 days. Growth performances (body weight, feed consumption, and feed conversion ratio $[\mathrm{FCR}]$ ), carcass traits (weight at slaughter, weight of the carcass, breast muscles, liver, lungs, kidneys, and heart), immune organs (spleen, thymus, and bursa of Fabricius), and non-edible organs (head, legs, and wings) were analyzed.

Results: Probiotic supplementation at 4 and $5 \mathrm{~mL} / \mathrm{kg}$ feed (T4 and T5) during the starter phase improved the body weight, FCR, and feed consumption. The weight at slaughter, weight of the carcass, breast muscles, and liver from the T4 and T5 groups were significantly greater than those in the other treatment groups. In addition, the weight of the heart, lungs, and kidneys was increased in the T1, T2, T3, T4, and T5 groups compared with that measured in the T0 group. Furthermore, there were significant differences regarding the immune organs between the T0 and the other treatment groups. The weight of the head, legs, and wings was also greater in the probiotic and AGP supplementation groups (T1, T2, T3, T4, and T5) than that in the basal feed group (T0).

Conclusion: Probiotic (L. acidophilus, L. plantarum, and Bifidobacterium spp.) supplementation at 4 and $5 \mathrm{~mL} / \mathrm{kg}$ feed during the starter period can be used to improve the growth, carcass traits, and weight of immune organs in male layer chicken.

Keywords: feed supplementation, growth performance, ISA brown layer chicken, probiotic, starter period.

\section{Introduction}

Chicken meat is one of the preferred animal protein sources in the Indonesian region [1]. Indeed, it is very popular and widely consumed by local people and is currently obtained from broiler and native chicken. Medium male layer chicken is the

Copyright: Agustono, et al. Open Access. This article is distributed under the terms of the Creative Commons Attribution 4.0 International License (http://creativecommons.org/licenses/ by/4.0/), which permits unrestricted use, distribution, and reproduction in any medium, provided you give appropriate credit to the original author(s) and the source, provide a link to the Creative Commons license, and indicate if changes were made. The Creative Commons Public Domain Dedication waiver (http:// creativecommons.org/publicdomain/zero/1.0/) applies to the data made available in this article, unless otherwise stated. meat-producing chicken of choice for the general public because the meat texture is similar to that of native chickens [2]. There are several advantages in using medium male layer chicken beside the meat quality, including the ease to market them, the cheaper cost of day-old chicks (DOCs), and the lower fat content compared with broilers $[3,4]$. DOCs are chicks in the early post-hatching period, which is considered a critical period for chicks [5]. The gastrointestinal tract of postnatal monogastric animals usually has an immature immune system, an unstable microbiota, and suboptimal endogenous enzyme secretion [6,7]. Farmers often use antibiotic growth promoters (AGPs) to 
improve the immune system in the starter phase. Administration of AGPs during the maintenance period of laying hens is also beneficial for the balance of the microbiota ecosystem and improves the digestibility of nutrients during the starter phase [8].

However, AGPs have long-term negative effects besides their beneficial effects on carcass quality and the immune system in laying hens [9]. Because of the detrimental effects of AGP administration (regarding both food safety and environmental impacts/residues) to chickens, the Indonesian government officially banned the use of AGPs as additives to animal feed in 2018 (Prohibition of the use of AGP in article 16 of the Regulation of the Minister of Agriculture Number 14 of 2017 concerning the Classification of Veterinary Drugs). The potential absorption of antibiotics in livestock products, including chicken meat, led to the prohibition of antibiotics as feed additives [10]. Using AGPs, low concentrations of antibiotics are ingested by consumers, potentially increasing chemical residues and bacterial resistance and causing allergic responses [11,12]. AGPs might be replaced with probiotics, and potential commercial applications of probiotic feed supplementation to enhance the growth performances of chicken have been shown [13].

Probiotics as non-antibiotics are used as alternative feed additives to improve digestion and absorption of nutrients in the intestines by supplying digestive enzymes, reducing the $\mathrm{pH}$, and increasing enzymatic activities in the digestive tract of chickens [14-16]. Probiotic supplementations contain beneficial microbiota, such as Lactobacillus spp. Furthermore, Bifidobacterium spp. has a positive impact on the gastrointestinal microbiota population. Probiotics increase the activity of digestive enzymes and consequently improve food absorption. Chickens can utilize Well-absorbed food for tissue growth and weight gain $[17,18]$. Probiotics (Lactobacillus acidophilus and Bifidobacterium spp.) have been shown to reduce the feed conversion ratios (FCRs) and affect the consumption of chicken proteins. Various doses of probiotics have been tested, but the exact dosage setting remains to be determined [19].

This study aimed to determine the efficacy of dietary supplementary probiotics as substitutes for AGPs during the starter period on growth performance, carcass traits, and immune organs in male layer chicken.

\section{Materials and Methods}

\section{Ethical approval}

The study was approved by the Ethical Committee of Faculty of Veterinary Medicine, Universitas Airlangga, Indonesia, with number 518/ HRECC.FODM/IX/2021.

\section{Study period and location}

This study was conducted for two months (August and September 2021). The DOCs were reared in the breeding farm located at Faculty Veterinary
Medicine, Universitas Airlangga. Proximate analysis of the feed was conducted at Laboratory of Animal Nutrition, Faculty of Veterinary Medicine, Universitas Airlangga. Variables examination was performed at the Laboratory of Animal Production, PSDKU Banyuwangi, Universitas Airlangga.

\section{Experimental design}

This study followed a completely randomized design. A total of 180 ISA brown males aged 1 day in the starter phase were divided into six treatment groups. Each treatment group consisted of three replication subgroups of 10 ISA brown males. Animals were housed in individual cages for layer chicken and fed with the treatment twice a day, in the morning and evening. Drinking water and feed were provided ad libitum.

The feed used in this study was complete feed. The nutritional content for the starter period is listed in Table-1 [20]. In the control group, the feed was not supplemented with AGP or probiotics, (T1) basal feed+2.5 g AGP/kg feed namely, virginiamycin, was added in $1 \mathrm{~kg}$ of feed and the mixture was prepared. (T2) basal feed+probiotics $1 \mathrm{~mL} / \mathrm{kg}$ feed, (T3) basal feed+probiotics $3 \mathrm{~mL} / \mathrm{kg}$ feed, (T4) basal feed+probiotics $4 \mathrm{~mL} / \mathrm{kg}$ feed, and (T5) basal feed+probiotics $5 \mathrm{~mL} / \mathrm{kg}$ feed. A solution containing $1.2 \times 10^{9}$ colony-forming unit $/ \mathrm{mL}$ of the probiotics L. acidophilus, Lactobacillus plantarum, and Bifidobacterium spp. was sprayed on the ISA brown stud feed using a spray and then air-dried for 5-10 min. Each treatment lasted for 21 days.

Table-1: Ingredients and calculated analysis of basal diet (gram in $1 \mathrm{~kg}$ basal diet) [20].

\begin{tabular}{lc}
\hline Ingredient (g) & Starter \\
\hline Corn & 482.61 \\
Soybean meal & 302.45 \\
Alfalfa meal & 61.38 \\
Poultry by-product meal & 50 \\
Poultry fat & 70.62 \\
Dicalcium phosphate & 14.75 \\
Limestone & 9.72 \\
Salt & 3.03 \\
DL-methionine & 2.19 \\
Vitamin-mineral premix & 2.50 \\
Coban & 0.75 \\
Total & 1000 \\
Calculated analysis (\%) & \\
Dry matter & 87 \\
Ash & 7 \\
Extract ether & 5 \\
Crude fiber & 5 \\
ME (kcal/kg) & 3.200 \\
Crude protein & 23 \\
Crude protein & 23.2 \\
Calcium & 1.0 \\
Available phosphorus & 0.5 \\
Methionine+cysteine & 0.93 \\
Lysine & 1.23 \\
Threonine & 0.97 \\
\hline ME=Metabolizable energy & \\
\hline
\end{tabular}

ME=Metabolizable energy 


\section{Sampling and measurements}

The feed efficacy was calculated using the chicken body weight and feed consumption following the formulas below. It was evaluated on days 1, 14, and 21 at 7 a.m.

Feed consumption $(\mathrm{g})=$ Amount of feed given (g)-Amount of unconsumed feed;

$\mathrm{FCR}=$ Feed consumption/Body weight;

Feed efficiency $=($ Body weight gain/Feed consumption) $\times 100$.

On $21^{\text {st }}$ day, the male layer chicken was sacrificed. The organs were collected to determine the carcass traits (weight of the animals at slaughter and weight of the carcass, breast muscles, liver, lungs, kidneys, and heart) and the weight of immune organs (spleen, thymus, and bursa of Fabricius) and non-edible organs (weight of the head, legs, and wings).

\section{Statistical analysis}

The data collected during the study were analyzed using Statistical Package for the Social Sciences version 26.0 software (IBM Corp., NY, USA) to analyze the variance with $p<0.05$ as the significance threshold. If there was a significant effect, the differences among groups were assessed with Duncan's multiple distance test $(5 \%)$.

\section{Results}

\section{Growth performances}

The growth performances of male layer chicken were assessed with body weight, FCR, and feed consumption. The body weight of animals from the $\mathrm{T} 1$ group was significantly increased than that from the T0 group (fed with $100 \%$ basal feed) (Figure-1). Furthermore, probiotic supplementation (L. acidophilus, L. plantarum, and Bifidobacterium spp.) at 1,4 , and $5 \mathrm{~mL} / \mathrm{kg}$ feed (T2, T4, and T5 groups, respectively) induced an increase in the body weight of male layer chicken compared with that of the T1 group receiving AGP (virginiamycin) supplementation (Table-2 and Figure-1).

There was a significant increase in consumption of male layer chicken receiving probiotic or AGP supplementations (Figure-2). Moreover, the feed consumption of the T4 and T5 groups was increased higher than that of the $\mathrm{T} 0$ and $\mathrm{T} 1$ groups. There was no difference in the feed consumption between the T2 and $\mathrm{T} 3$ groups and the $\mathrm{T} 4$ and $\mathrm{T} 5$ groups during the starter phase of this study (Table-2).
Figure- 3 shows a decreased FCR of male layer chicken receiving AGP supplementation and even more in those treated with probiotics. The FCR of the T4 and T5 groups was decreased than those of the other treatment groups. These results indicated that probiotic supplementation at 4 or $5 \mathrm{~mL} / \mathrm{kg}$ feed

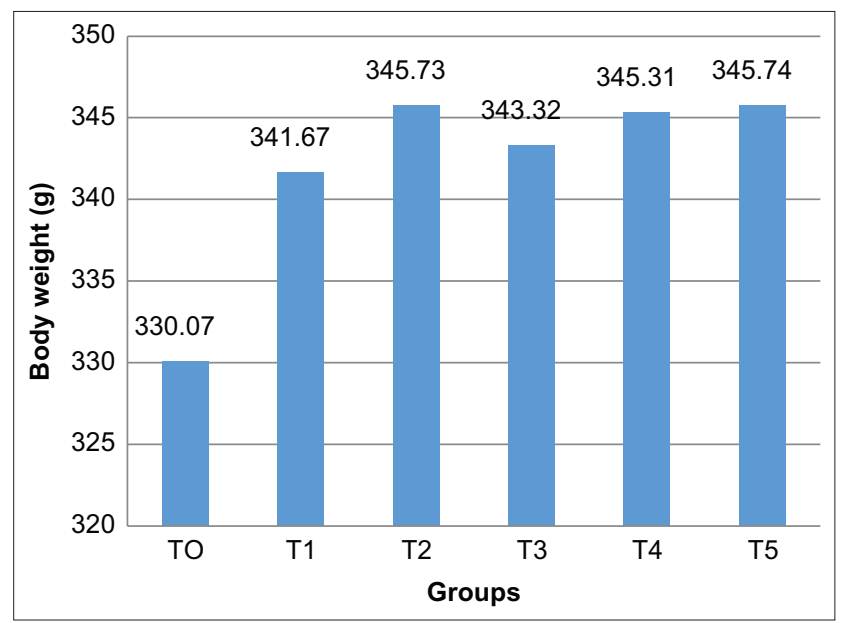

Figure-1: Efficacy of dietary supplementary probiotics on male layer chicken body weight during starter period. Values are expressed in mean \pm standard error. One-way analysis of variance was carried out followed by Duncan's comparison test. $a, b, c$ Different superscripts indicate significant differences $(p<0.05)$.

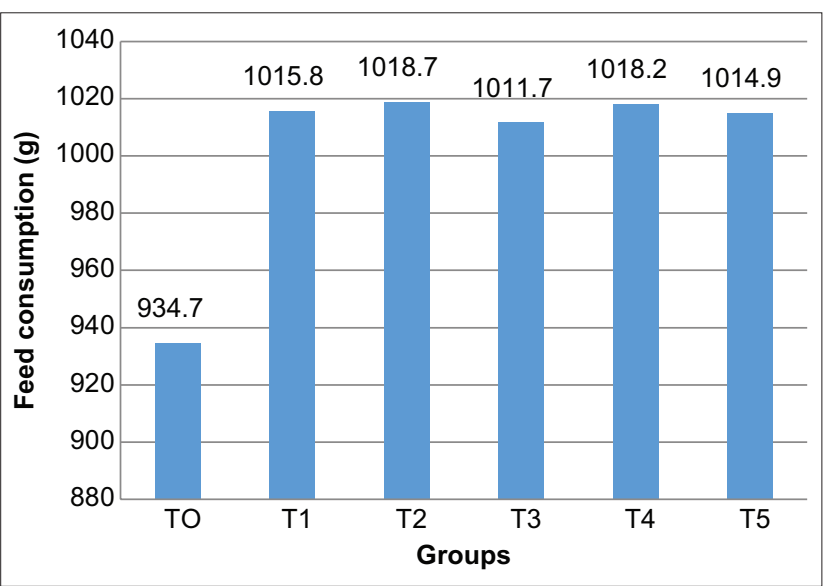

Figure-2: Efficacy of dietary supplementary probiotics on feed consumption of male layer chicken during the starter period. Values are expressed in mean \pm standard error. One-way analysis of variance was carried out, followed by Duncan's comparison test. ${ }^{a}, b, c$ Different superscripts indicate significant differences $(p<0.05)$.

Table-2: Growth performance of male layer chicken fed different experimental diets during the starter period.

\begin{tabular}{lcccccc}
\hline Variables & T0 & T1 & T2 & T3 & T4 & T5 \\
\hline Initial weight $(\mathrm{g})$ & $42.560 \pm 0.105^{\mathrm{a}}$ & $42.547 \pm 0.112^{\mathrm{a}}$ & $42.573 \pm 0.109^{\mathrm{a}}$ & $42.560 \pm 0.129^{\mathrm{a}}$ & $42.560 \pm 0.118^{\mathrm{a}}$ & $42.547 \pm 0.124^{\mathrm{a}}$ \\
Body weight $(\mathrm{g})$ & $330.07 \pm 6.15^{\mathrm{a}}$ & $341.67 \pm 2.44^{\mathrm{b}}$ & $345.73 \pm 4.94^{\mathrm{c}}$ & $343.32 \pm 3.67^{\mathrm{b}, \mathrm{c}}$ & $345.31 \pm 2.37^{\mathrm{c}}$ & $345.74 \pm 3.48^{\mathrm{c}}$ \\
Feed & $934.7 \pm 3.5^{\mathrm{a}}$ & $1015.8 \pm 3.8^{\mathrm{b}}$ & $1018.7 \pm 3.8^{\mathrm{b}, \mathrm{c}}$ & $1011.7 \pm 5.5^{\mathrm{c}, \mathrm{c}}$ & $1018.2 \pm 3.8^{\mathrm{c}}$ & $1014.9 \pm 4.3^{\mathrm{c}}$ \\
$\begin{array}{l}\text { consumption }(\mathrm{g}) \\
\text { Feed conversion }\end{array}$ & $3.040 \pm 0.04^{\mathrm{a}}$ & $2.957 \pm 0.03^{\mathrm{b}}$ & $2.964 \pm 0.03^{\mathrm{b}}$ & $2.946 \pm 0.02^{\mathrm{b}}$ & $2.890 \pm 0.03^{\mathrm{c}}$ & $2.877 \pm 0.04^{\mathrm{c}}$ \\
ratio (kg/kg gain) & & & & & &
\end{tabular}

$a, b, c$ Different superscripts in the same raw show significant difference $(p<0.05)$. (T0) $100 \%$ basal feed, (T1) basal feed+2.5 g AGP/kg feed, (T2) basal feed+probiotic $1 \mathrm{~mL} / \mathrm{kg}$ feed, (T3) basal feed+probiotics $3 \mathrm{~mL} / \mathrm{kg}$ feed, (T4) basal feed+probiotic $4 \mathrm{~mL} / \mathrm{kg}$ feed, and (T5) basal feed+probiotic $5 \mathrm{~mL} / \mathrm{kg}$ feed. AGP=Antibiotic growth promoter 


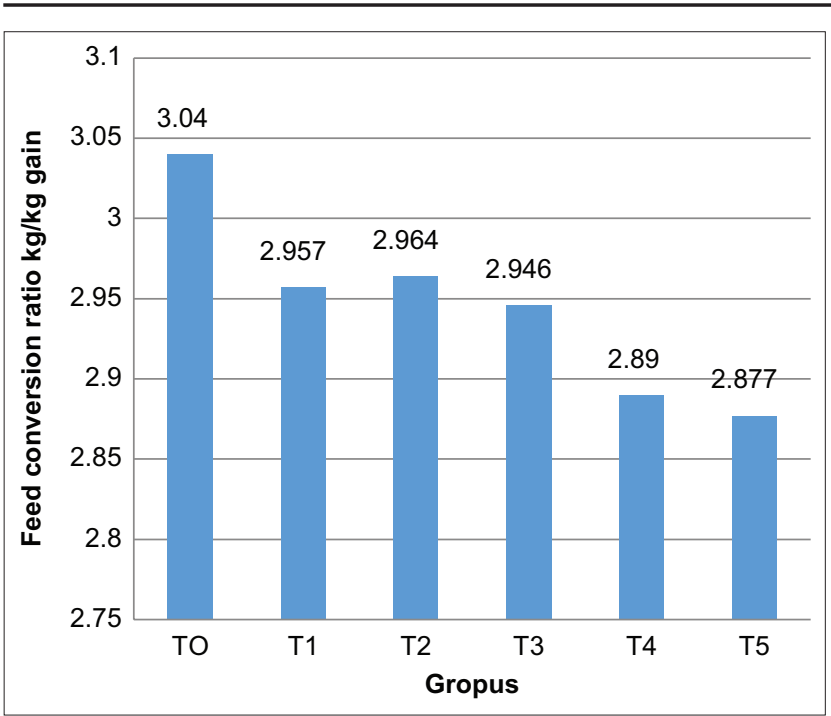

Figure-3: Efficacy of dietary supplementary probiotics on feed conversion ratio of male layer chicken during the starter period. Values are expressed in mean \pm standard error. One-way analysis of variance was carried out, followed by Duncan's comparison test. a,b,cDifferent superscripts indicate significant differences $(p<0.05)$.

improved the body weight, FCR, and feed consumption during the starter.

\section{Carcass traits}

In general, probiotic supplementation ( $L$. acidophilus, L. plantarum, and Bifidobacterium spp.) at 4 and $5 \mathrm{~mL} / \mathrm{kg}$ feed (T4 and T5) induced an increase in the weight at slaughter of the animal, breast muscles, and liver compared with that measured in the other treatment groups. Furthermore, the heart, kidney, and lung weights in animals treated with AGP or probiotics increased greater than those of the group receiving $100 \%$ basal feed (T0) (Table-3).

\section{Immune organs}

There were significant differences between the T0 group and the other treatment groups $(\mathrm{p}<0.05)$ (Table-3) regarding the weight of immune organs, including the spleen, bursa of Fabricius, and thymus. The lowest weights were found for the spleen, bursa of Fabricius, and thymus of the T0 group (100\% basal feed). In contrast, the spleen and bursa of Fabricius weights of animals receiving probiotic and AGP supplementations (T1, T2, T3, T4, and T5) were the greatest. The thymus weight was also increased in the groups treated with probiotics at 4 and $5 \mathrm{~mL} / \mathrm{kg}$ feed (T4 and T5) than in other treatment groups (Table-3).

\section{Non-edible organs}

The weight of the head, legs, and wings was more significant in groups receiving probiotic or AGP supplementation (T1, T2, T3, T4, and T5) than those measured in the basal feed group (T0) (Table-3).

\section{Discussion}

In this study, the supplementation of feed with probiotics (L. acidophilus, L. plantarum, and Bifidobacterium spp.) in male layer chicken during the starter period led to an increase in feed consumption and body weight and a decrease of the FCR. These probiotics might reduce the FCR and increase the body weight by improving the digestibility and absorption of nutrients in male layer chicken during the starter period. As shown previously [21], the use of probiotics leads to significant differences in growth performances, weight gain, feed intake, and FCR during the starter phase. The higher feed consumption has been linked to a decreased gastric emptying time when probiotics are provided in the feed [22].

In addition, Lactobacillus use was reported to support the host cecal microbiota effects of increasing feed efficiency and body weight and decreasing FCR [23-25]. The administration of Lactobacillus spp. and Bacillus cereus in broiler chicken also reduces the $\mathrm{pH}$ of the ileum and cecum by increasing fatty acids. This has a positive antibacterial impact as it reduces the amount of Escherichia coli [26-28]. The growth of pathogenic bacteria is indeed inhibited in an acidic environment in the digestive tract, allowing beneficial bacteria to be dominant in the digestive tract. The decreased $\mathrm{pH}$ in the digestive tract also increases the motility of the intestinal wall layer so that the surface area, and consequently the absorption of the intestinal wall increases $[29,30]$. Therefore, probiotic supplementation positively impacts the development of the intestinal tract in the starter period by maintaining the balance of the gastrointestinal microbiota, which leads to increased feeding and weight gain in broilers [30,31].

The positive impact on body weight and feed conversion might be influenced by the ability of probiotic bacteria to produce enzymes such as cellulases, amylases, and proteases, which can significantly increase nutrient digestibility and increase the body weight of broilers $[24,32,33]$. However, several studies showed that probiotic supplementation reduces feed consumption [25] and increases FCR in broilers [34]. These different effects of diet enrichment with probiotics might be caused by several factors, including the chicken sex, the chicken developmental phase, the dose of probiotics, and the type of probiotics $[24,31]$.

The weight at slaughter and the carcass, liver, and heart were increased in groups treated with AGP (T1) or probiotics (T2, T3, T4, and T5) compared with those of the control $\mathrm{T} 0$ group. The increase in weight at slaughter and carcass might be caused by the increased nutrient digestibility, enzyme activity, and a favorable balance of the gastrointestinal microbiota induced by the addition of probiotics in the feed $[3,35]$. These data are in agreement with a previous work [36] showing an increase in carcass yield and relative weight of the intestinal tract, as well as a decrease in abdominal fat in the fermented canola meal group, compared with those of the groups receiving canola meal and canola meal with probiotics. The addition of probiotics in feed might lead to a higher carcass weight by increasing the availability 


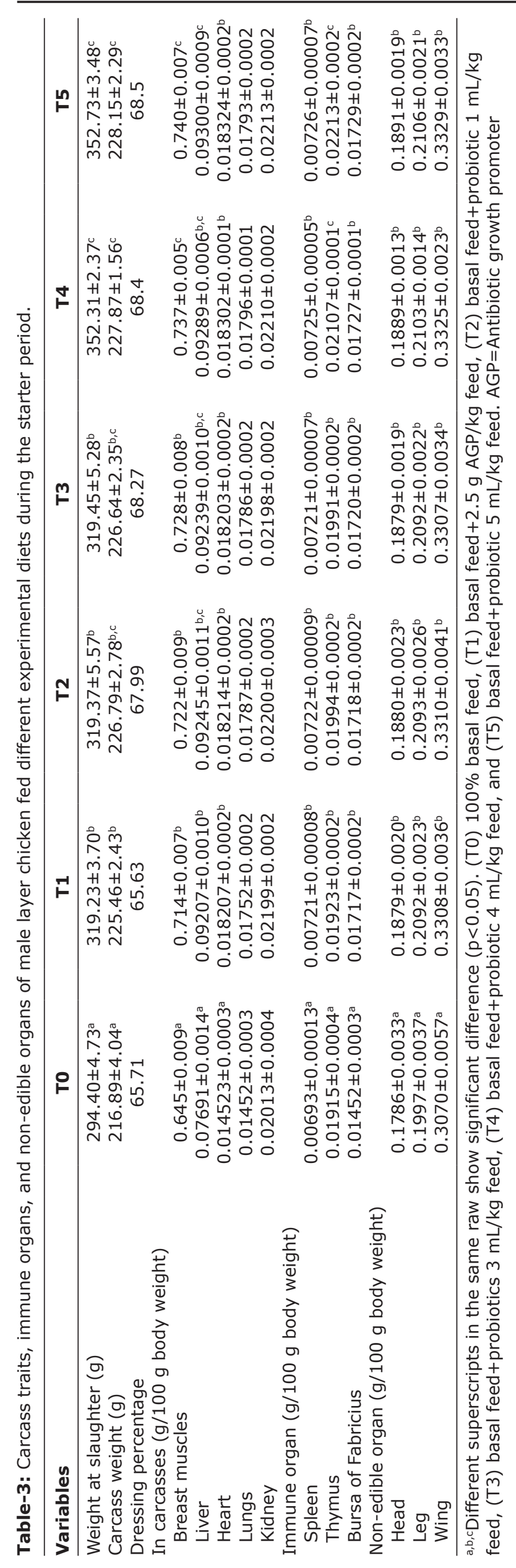

of protein in the body [37]. In addition, probiotic inclusion significantly affects growth responses, including body weight and nutrient digestibility [38], and carcass weight [14]. However, the effects of probiotic administration on carcass quality, slaughter weight, breast weight, and organs (liver, heart, and gizzard) were significantly related to the sex of chickens [39-41].

A significantly higher weight of immune organs (bursa of Fabricius) has been shown in animals fed with fermented canola meal and canola meal supplemented with probiotics compared with the weight in other treatment groups and control group [36]. The increase in the relative weight of the bursa of Fabricius is likely due to an increase in the lymphocyte levels induced by the addition of probiotic microbiota to stimulate the immune response of chickens $[26,42]$. The weight of other immune organs, such as the spleen and thymus, was not significantly different among treatment groups [36]. However, after probiotic administration, weighing lymphoid organs (spleen, bursa of Fabricius, and thymus) showed a significant change in the spleen relative weight on 42 days of age compared to the control group. This might be because the function of lymphoid organs develops with the developmental age of chickens [42]. However, different results were also obtained [43], showing no significant effect on the spleen weight of probiotics addition in chicken feed.

Non-edible body parts of chickens include bones and slaughter offal (feathers, wings, head, and leg) [44]. In the present study, the administration of probiotics affected, albeit small, on the weight of the wings, head, and leg. This result most likely reflects the positive correlation between body weight and linear body measurements, which means that all linear body traits increase simultaneously with the chicken body weight [44]. This agrees with the previous reports $[45,46]$ of a positive and significant correlation between linear body size and body weight. However, there are conflicting findings regarding the positive correlation between linear body parameters and body weight in poultry $[47,48]$. The differences in body weight indicate that the administration of probiotics to male layer chicken at the starter period affects chickens and consequently affects the measurement of other organs, especially non-edible organs.

\section{Conclusion}

Probiotic (L. acidophilus, L. plantarum, and Bifidobacterium spp.) supplementation during the starter period might improve the growth, carcass traits, and immune organ size of male layer chicken. It is necessary to conduct more in-depth study on the level of digestibility and activity of digestive enzymes with the addition of probiotics in male layer chicken of the ISA Brown strain.

\section{Authors' Contributions}

BA: Supervised the study. WPL, MNY, AEC, and RNK: Conducted the study. WPL: Statistical analysis 
of the data. SW: Drafted the manuscript. WPL and MNY: Revised the manuscript. All authors read and approved the final manuscript.

\section{Acknowledgments}

We thank the Rector of Universitas Airlangga and Dean of Faculty of Veterinary Medicine, Universitas Airlangga, Indonesia, for providing funding to conduct this research (Grant number 658/UN3.15/PT/2021).

\section{Competing Interests} interests.

The authors declare that they have no competing

\section{Publisher's Note}

Veterinary World remains neutral with regard to jurisdictional claims in published institutional affiliation.

\section{References}

1. Setiadi, D., Nova, K. and Tantalo, S. (2003) Comparison of Live Weight, Carcass, Giblet, and Abdominal Fat of Medium Type Roosters with Different Strains Given Commercial Broiler Ration No. 3.

2. Rahmat, N., Rudy, S. and Khaira, N. (2015) Effect of rations with different percentages of crude fiber on the performance of medium-type roosters aged 3-8 weeks. J. Ilm. Peternak. Terpadu, 3(2): 12-19.

3. Haryadi, R.D., Sutrisna, R. and Kurtini, T. (2015) Effect of the different coarse fibrous ration on live weight and carcass of medium type roosters at 8 weeks of age. J. Ilm. Peternak. Terpadu, 3(2): 85 .

4. Marwi, F., Sjofjan, O., Muttaqin, A. and Natsir, M.H. (2021) Effect of probiotics and magnetic technology in drinking water on production performance and egg quality of laying hens. J. Worlds Poult. Res., 11(2): 204-209.

5. Nichelmann, M. and Tzschentke, B. (2002) Ontogeny of thermoregulation in precocial birds. Comp. Biochem. Physiol. A Mol. Integr. Physiol., 131(4): 751-763.

6. Kim, E., Akhtar, N., Li, J., Hui, Q., Dong, B., Yang, C. and Kiarie, E.G. (2020) In ovo feeding of epidermal growth factor: Embryonic expression of intestinal epidermal growth factor receptor and post hatch growth performance and intestinal development in broiler chickens. Poult. Sci., 99(11): 5736-5743.

7. Pluske, J.R. (2016) Invited review: Aspects of gastrointestinal tract growth and maturation in the pre-and post-weaning period of pigs. J. Anim. Sci., 94(7): 399-411.

8. Samuel, K.G., Wang, J., Yue, H.Y., Wu, S.G., Zhang, H.J., Duan, Z.Y. and Qi, G.H. (2017) Effects of dietary gallic acid supplementation on performance, antioxidant status, and jejunum intestinal morphology in broiler chicks. Poult. Sci., 96(8): 2768-2775

9. Vanderhaeghen, W. and Dewulf, J. (2017) Antimicrobial use and resistance in animals and human beings. Lancet Planet. Health, 1(8): e307-e308.

10. Permentan. (2017) Regulation of the Minister of Agriculture Republic Indonesia Nomor14/PERMENTAN/ PK.350/5/2017 about Classification of Animal Medicine. Ministry of Agriculture, Jakarta.

11. WHO. (2018) Technical Series on Primary Health Care, Antimicrobial Resistance and Primary Health Care No. 3-6.

12. Ferri, M., Ranucci, E., Romagnoli, P. and Giaccone, V. (2017) Antimicrobial resistance: An emerging global threat to public health systems. Crit. Rev. Food Sci. Nutr., 57(13): 2857-2876.

13. Mikulski, D., Jankowski, J., Naczmanski, J., Mikulska, M., and Demey, V. (2012) Effects of dietary probiotic
(Pediococcus acidilactici) supplementation on performance, nutrient digestibility, egg traits, egg yolk cholesterol, and fatty acid profile in laying hens. Poult. Sci., 91(10): 2691-2700.

14. Abd El-Hack, M.E., El-Saadony, M.T., Shafi, M.E., Qattan, S.Y.A., Batiha, G.E., Khafaga, A.F., AbdelMoneim, A.M.E. and Alagawany, M. (2020) Probiotics in poultry feed: A comprehensive review. J. Anim. Physiol. Anim. Nutr. (Berl.), 104(6): 1835-1850.

15. Kabir, S.M.L. (2003) The Dynamics of Probiotics in Enhancing Poultry Meat Production and Quality, MS Thesis.

16. Agustono, B., Al Arif, M.A., Yunita, M.N., Purnama, M.T.E. and Ulkhaq, F. (2019) Bioactivity of digestive enzymes and histological descriptions of jejunum of broilers supplemented with sunflower seed flour (Helianthus annuus L). Indian Vet. J., 96(8): 12-15.

17. S. Sandhya, K. Venkatramana, K.R. Vinod, R.K. Chaitanya, J. Chandrasekhar1, K. Sudhakar and T. Rajeswar. (2010) Membrane stabilizing potency of two Tephrosia species. J. Phytology, 2(6): 42-46.

18. Astuti, F.K., Busono, W. and Sjofjan, O. (2015) P effect of addition of liquid probiotics in feed to production appearance in broilers. Pembang. Alam Lestari., 6(2): 99-104.

19. Getachew, T. (2016) A review on effects of probiotic supplementation in poultry performance and cholesterol levels of egg and meat. J. World Poult. Res., 6(61): 31-36.

20. Roush, W.B., Boykin, D. and Branton, S.L. (2004) Optimization of phase feeding of starter, grower, and finisher diets for male broilers by mixture experimental design: Forty-eight-day production period. Poult. Sci., 83(8): 1264-1275.

21. Rehman, A., Arif, M., Sajjad, N., Al-Ghadi, M.Q., Alagawany, M., Abd El-Hack, M.E., Alhimaidi, A.R., Elnesr, S.S., Almutairi, B.O., Amran, R.A., Hussein, E.O.S. and Swelum, A.A. (2020) Dietary effect of probiotics and prebiotics on broiler performance, carcass, and immunity. Poult. Sci., 99(12): 6946-6953.

22. Abdel-Raheem, S.M. and Abd-Allah, S.M.S. (2011) The effect of single or combined dietary supplementation of mannan oligosaccharide and probiotics on performance and slaughter characteristics of broilers. Int. J. Poult. Sci., 10(11): 854-862.

23. Yan, W., Sun, C., Yuan, J. and Yang, N. (2017) Gut metagenomic analysis reveals prominent roles of Lactobacillus and cecal microbiota in chicken feed efficiency. Sci. Rep., 7. 45308

24. Bedford, M. (2000) Removal of antibiotic growth promoters from poultry diets: Implications and strategies to minimise subsequent problems. Worlds Poult. Sci. J., 56(4): 362-365.

25. Amerah, A.M., Quiles, A., Medel, P., Sánchez, J., Lehtinen, M.J. and Gracia, M.I. (2013) Effect of pelleting temperature and probiotic supplementation on growth performance and immune function of broilers fed maize/soybased diets. Anim. Feed Sci. Technol., 180(1-4): 55-63.

26. Li, S.P., Zhao, X.J. and Wang, J.Y. (2009) Synergy of Astragalus polysaccharides and probiotics (Lactobacillus and Bacillus cereus) on immunity and intestinal microbiota in chicks. Poult. Sci., 88(3): 519-525.

27. Watkins, B.A., Miller, B.F. and Neil, D.H. (1982) In vivo inhibitory effects of Lactobacillus acidophilus against pathogenic Escherichia coli in gnotobiotic chicks. Poult. Sci., 61(7): 1298-1308.

28. Forte, C., Acuti, G., Manuali, E., Casagrande Proietti, P., Pavone, S., Trabalza-Marinucci, M., Moscati, L., Onofri, A., Lorenzetti, C. and Franciosini, M.P. (2016) Effects of two different probiotics on microflora, morphology, and morphometry of gut in organic laying hens. Poult. Sci., 95(11): 2528-2535.

29. Lokapirnasari, W.P., Dewi, A.R., Fathinah, A., Hidanah, S., Harijani, N., Soeharsono, Karimah, B. and Andriani, A.D. 
(2017) Effect of probiotic supplementation on organic feed to alternative antibiotic growth promoter on production performance and economics analysis of quail. Vet. World, 10(12): 1508-1514.

30. Lokapirnasari, W.P., Pribadi, T.B., Al Arif, A., Soeharsono, S., Hidanah, S., Harijani, N., Najwan, R., Huda, K., Wardhani, H.C.P., Rahman, N.F.N. and Yulianto, A.B. (2019) Potency of probiotics Bifidobacterium spp. and Lactobacillus casei to improve growth performance and business analysis in organic laying hens. Vet. World, 12(6): 860-867.

31. Hamasalim, H.J. (2016) Synbiotic as feed additives relating to animal health and performance. Adv. Microbiol., 6(4): 288-302.

32. Smith, J.M. (2014) A review of avian probiotics. J. Avian Med. Surg., 28(2): 87-94.

33. Chaucheyras-Durand, F. and Durand, H. (2010) Probiotics in animal nutrition and health. Benef. Microbes, 1(1): 3-9.

34. Sohail, M.U., Hume, M.E., Byrd, J.A., Nisbet, D.J., Ijaz, A., Sohail, A., Shabbir, M.Z. and Rehman, H. (2012) Effect of supplementation of prebiotic mannan-oligosaccharides and probiotic mixture on growth performance of broilers subjected to chronic heat stress. Poult. Sci., 91(9): 2235-2240.

35. Shim, Y.H., Shinde, P.L., Choi, J.Y., Kim, J.S., Seo, D.K., Pak, J.I., Chae, B.J. and Kwon, I.K. (2010) Evaluation of multi-microbial probiotics produced by submerged liquid and solid substrate fermentation methods in broilers. AsianAustralas. J. Anim. Sci., 23(4): 521-529.

36. Elbaz, A.M. (2021) Effects of the diet containing fermented canola meal on performance, blood parameters, and gut health of broiler chickens. J. Worlds Poult. Res., 11(1): 1-7.

37. Nyoman, I.G., Bidura, G.D.E., Siti, N.I.W. and Puspani, E. (2018) Implementation of Probiotics in Diets on Body Weight and Distribution of Fat in Ducks Body, International Conference Science No. 80223.

38. Mountzouris, K.C., Tsitrsikos, P., Palamidi, I., Arvaniti, A., Mohnl, M., Schatzmayr, G. and Fegeros, K. (2010) Effects of probiotic inclusion levels in broiler nutrition on growth performance, nutrient digestibility, plasma immunoglobulins, and cecal microflora composition. Poult. Sci., 89(1):
58-67.

39. Acar, N., Moran, E.T. and Mulvaney, D.R. (1993) Breast muscle development of commercial broilers from hatching to twelve weeks of age. Poult. Sci., 72(2): 317-325.

40. Brake, J., Havenstein, G.B., Scheideler, S.E., Ferket, P.R. and Rives, D.V. (1993) Relationship of sex, age, and body weight to broiler carcass yield and offal production. Poult. Sci., 72(6): 1137-1145.

41. Brzóska, F., Śliwiński, B. and Stecka, K. (2012) Effect of Lactococcus lactis vs. lactobacillus spp. bacteria on chicken body weight, mortality, feed conversion, and carcass quality. Ann. Anim. Sci., 12(4): 549-559.

42. Alkhalf, A., Alhaj, M. and Al-Homidan, I. (2010) Influence of probiotic supplementation on the immune response of broiler chicks. Egypt. Poult. Sci., 30(30): 271-280.

43. Teo, A.Y. and Tan, H.M. (2007) Evaluation of the performance and intestinal gut microflora of broilers fed on corn-soy diets supplemented with Bacillus subtilis PB6 (CloSTAT). J. Appl. Poult. Res., 16(3): 296-303.

44. Petrus, N.P., Kangootui, K., Kandiwa, E., Madzingira, O. and Mushonga, B. (2019) Relationship of age and live weight to linear body traits in female intensively reared Boschveld chicken in Namibia. Int. J. Poult. Sci., 18(10): 483-491.

45. Yahaya, H.K., Ibrahim, H. and Abdulsalam, S. (2012) Correlation between body weight and body conformation of two broiler strains under the same dietary treatment. Int. J. Anim. Vet. Adv., 4(3): 181-183.

46. Sadick A. M, Aryee G, Poku Jnr and Gyeabour G (2020) Relationship between body weight and linear body measurements in Cobb broiler chickens. World J. Biol. Pharm. Health Sci., 04(02), 001-006

47. Weight, M. (2016) Using early live body performance traits of ducks to predict marketing weight. Egypt. Poult. Sci. J., 36(4): 895-904.

48. Ekka, R., Behura, N.C., Samal, L., Nayak, G.D. and Pati, P.K. (2016) Growth performance and linear body measurements of Hansli, CSML and Hansli $\times$ CSML cross under intensive system of rearing. J. Livest. Sci., 7: 114-121.

\section{$* * * * * * * *$}

